\title{
Wpływ wsparcia z funduszy unijnych na rozwój rolnictwa ekologicznego w Polsce
}

\author{
JOLANTA KONDRATOWICZ-POZORSKA \\ dr hab. prof. PK, Politechnika Koszalińska, Wydział Nauk Ekonomicznych \\ e-mail: jolanta.pozorska@tu.koszalin.pl
}

SŁoWA KLUCZOWE ekologiczne gospodarstwa rolne, unijne programy wsparcia

Abstrakt Cel-sprawdzenie na ile finansowanie działalności rolnej z funduszy Unii Europejskiej miało i ma wpływ na rozwój rolnictwa ekologicznego w Polsce.

Metodyka badania - dokonano przeglądu literatury naukowej korespondującej z tematem pracy, zebrano i przeanalizowano raporty i ekspertyzy z Ministerstwa Rolnictwa i Rozwoju Wsi, Głównego Inspektoratu Jakości Artykułami Rolno-Spożywczymi (IJHARS), Instytutu Ekonomiki Rolnictwa i Rozwoju Wsi PAN, a także opracowania instytucji zagranicznych do spraw rolnictwa, takich jak Research Institute of Organic Agriculture (FiBL), Międzynarodowej Federacji Rolnictwa Ekologicznego (IFOAM).Wykorzystano współczynnik korelacji Pearsona do przedstawienia zależności pomiędzy wydatkami z funduszy unijnych a przyrostem gospodarstw ekologicznych w Polsce oraz policzono wskaźniki dynamiki obrazujące zmiany w wydatkach z funduszy unijnych.

Wynik-znaczące fundusze unijne zasilające ekologiczne gospodarstwa rolne w Polsce po 2004 roku sprawiły, że rolnicy coraz chętniej dostosowywali swoje gospodarstwa do tych metod produkcji, które dawały najwyższe dotacje. Tak m.in. wywołano lawinowy wzrost liczby i powierzchni ekologicznych gospodarstw rolnych na terenie Polskie w latach 2004-2013. Po roku 2010 niewielki przyrost środków finansowych przypadający na gospodarstwo i/lub na 1 ha wprowadził jednak niepokój wśród rolników. Ten czynnik i niepewność co do dalszej polityki wsparcia rolnictwa przez UE sprawiło, że od 2013 roku obserwuje się regres rolnictwa ekologicznego.

Wartość - wraz ze spadkiem wsparcia finansowego ekologicznych gospodarstw rolnych spadkowi ulegnie ich liczba i powierzchnia gospodarowania.

\section{The EU funds and the development of organic farming in Poland}

KeYWords

ABSTRACT ecological farms, EU support programs

Purpose - the purpose of this paper is to check on how much financing of agricultural funds and the European Union had impact on the development of organic farming in Poland.

Methodology - a review of the scientific literature and the author analyzed the reports and expertise of the Ministry of Agriculture and Rural Development and the IJHARS, the Institute of Agricultural Economics and Rural Development Academy, as well as the development of foreign institutions to for agriculture, such FiBL and IFOAM.

Findings - the EU funds supply organic farms in Poland after 2004 meant that farmers are increasingly eager to have adapted their farms to the production methods, which gave the highest subsidies. This 
situation caused a rapid increase in the number and size of organic farms in Polish in the years 2004-2013. However, after 2010, a slight increase in funding per 1 farm and/or 1 ha brought anxiety among farmers. This factor and the uncertainty as to further policy support to agriculture by the EU meant that from 2013 is regressing farming.

Value - with decreasing financial support of organic farms will decrease their number and area management.

\section{Wprowadzenie}

Wydawać by się mogło, że rolnictwo ekologiczne to nowy trend w rolnictwie i odpowiedź rolników na zachowania współczesnych konsumentów, którzy chcą żyć według zasady „,w zgodzie z naturą". Tymczasem rolnictwo ekologiczne ma blisko stuletnią tradycję. Jego początki datowane są na 1924 rok i związane z Polską oraz oddolną inicjatywą obywatelską (ruchem społecznym) propagującą naturalne sposoby uprawy roślin i chowu zwierząt (Tyburski, Żakowska-Biemans, 2007, s. 5). Później w Szwajcarii, Wielkiej Brytanii oraz we Francji wypracowano różne pokrewne metody rolnictwa ekologicznego, jak rolnictwo biodynamiczne, organiczno-biologiczne, organiczne czy biologiczne. W Europie Zachodniej do końca lat 80. XX wieku, a w Polsce aż do początku XXI wieku, rolnictwo ekologiczne było jednak traktowane raczej eksperymentalnie. Dopiero przełom lat 80. i 90. XX wieku przyniósł gwałtowny rozwój tej formy rolnictwa na zachodzie Europy. Jak podaje Kondratowicz-Pozorska (2013) w dużej mierze był to efekt synergii wielu czynników, wśród których najczęściej wymienia się: wzrost zamożności społeczeństw, nadwyżki konwencjonalnych produktów rolnych w sklepach, wzrost liczby zachorowań na tzw. choroby cywilizacyjne jak cukrzyca, nadciśnienie, otyłość, a także korzystne działania instytucji unijnych wspierających finansowo działania innowacyjne, prorozwojowe i korzystne dla środowiska naturalnego.

Celem niniejszego artykułu jest sprawdzenie na ile finansowanie działalności rolnej z funduszy Unii Europejskiej miało i ma wpływ na rozwój rolnictwa ekologicznego w Polsce. W tym celu dokonano przeglądu literatury naukowej, zebrano i przeanalizowano raporty i ekspertyzy z Ministerstwa Rolnictwa i Rozwoju Wsi, Głównego Inspektoratu Jakości Artykułami Rolno-Spożywczymi (IJHARS), Instytutu Ekonomiki Rolnictwa i Rozwoju Wsi PAN, a także opracowania instytucji zagranicznych ds. rolnictwa, takich jak Research Institute of Organic Agriculture (FiBL), Międzynarodowej Federacji Rolnictwa Ekologicznego (IFOAM).

\section{Wsparcie finansowe rolnictwa ekologicznego w Polsce}

W kraju rolnictwo ekologiczne po raz pierwszy było dofinansowane jeszcze przed wstąpieniem Polski do UE. W roku 1998 z budżetu państwa wypłacono dotacje do kosztów kontroli gospodarstw ekologicznych, które udzielane były jednostkom przeprowadzającym kontrolę. A w kolejnym roku dodano dotację do powierzchni upraw ekologicznych. Beneficjentami wsparcia byli zatem rolnicy prowadzący ekologiczne gospodarstwa rolne lub będący w trakcie przestawiania gospodarstwa z konwencjonalnego na ekologiczne (Kondratowicz-Pozorska, 2014, s. 108). Siła wsparcia finansowego była jednak słaba, a ryzyko związane z tym, że efekt produkcji 
ekologicznej będzie niewielki - zbyt wysokie, więc nie odnotowano masowego przystępowania rolników do proponowanych programów ani też większego zainteresowania zmianą dotychczasowych metod produkcji. W sumie w 1999 roku łączna kwota dotacji do upraw ekologicznych i do kosztów kontroli wynosiła 674 273,5 zł (Rolnictwo ekologiczne..., 2001, s. 11). Na koniec 2000 roku powierzchnia upraw ekologicznych wynosiła od 12,7 do 25 tys. ha' ${ }^{1}$, tj. około 0,15\% powierzchni użytków rolnych Polski, natomiast na dzień 31.12.2014 roku odnotowano, że 657 902,06 ha ziemi było użytkowane metodami ekologicznymi. Stanowiło to już 4,04\% powierzchni użytków rolnych kraju.

W 2014 roku po raz pierwszy od 10 lat zauważono spadek zarówno liczby ekologicznych gospodarstw rolnych, jak i ich powierzchni. Analizując dane zawarte w tabeli 1 można stwierdzić, że notowania z roku 2014 w stosunku do roku 2013 dotyczące liczby ekologicznych gospodarstw są niższe o $6,7 \%$, co daje spadek powierzchni upraw o 1,8\%, podczas gdy liczba producentów ekologicznych nadal rosła - o 18,9\%. Gdy porównuje się dane z lat 2015 w stosunku do 2014 sytuacja wygląda podobnie - zauważono analogiczny spadek liczby ekologicznych gospodarstw o 7,3\%, co zmniejsza powierzchnię upraw o 11,7\%, podczas gdy liczba producentów ekologicznych kolejny raz rośnie o $16,1 \%$.

Tabela 1. Powierzchnia i liczba ekologicznych gospodarstw rolnych oraz liczby przetwórni ekologicznych w Polsce w wybranych latach

\begin{tabular}{|c|c|c|c|c|c|c|}
\hline \multirow{2}{*}{ Rok } & \multicolumn{2}{|c|}{$\begin{array}{c}\text { Ekologiczne } \\
\text { gospodarstwa rolne }\end{array}$} & \multicolumn{2}{c|}{$\begin{array}{c}\text { Ekologiczne } \\
\text { przetwórnie }\end{array}$} & \multicolumn{2}{c|}{$\begin{array}{c}\text { Powierzchnia ekologicznych } \\
\text { użytków rolnych }\end{array}$} \\
\cline { 2 - 7 } & liczba & $\begin{array}{c}\text { dynamika rok } \\
\text { do roku (\%) }\end{array}$ & liczba & $\begin{array}{c}\text { dynamika rok } \\
\text { do roku (\%) }\end{array}$ & tys. ha & $\begin{array}{c}\text { dynamika rok } \\
\text { do roku (\%) }\end{array}$ \\
\hline 1999 & 513 & - & b.d & - & 6,99 & - \\
\hline 2004 & 3705 & 722,2 & 55 & - & 83,7 & 1197,4 \\
\hline 2005 & 7183 & 193,9 & 99 & 180,0 & 166,3 & 198,7 \\
\hline 2006 & 9189 & 127,9 & 170 & 171,7 & 228,0 & 137,1 \\
\hline 2007 & 11870 & 129,2 & 206 & 121,2 & 287,5 & 126,1 \\
\hline 2008 & 14896 & 125,5 & 236 & 114,6 & 314,9 & 109,5 \\
\hline 2009 & 17091 & 114,7 & 277 & 117,4 & 416,3 & 132,2 \\
\hline 2010 & 20582 & 120,4 & 293 & 105,8 & 519,1 & 124,7 \\
\hline 2011 & 23449 & 113,9 & 270 & 92,1 & 605,5 & 116,6 \\
\hline 2012 & 25944 & 110,6 & 313 & 115,9 & 661,7 & 109,3 \\
\hline 2013 & 26598 & 102,5 & 407 & 130,0 & 667,0 & 100,8 \\
\hline 2014 & 24829 & 93,3 & 484 & 118,9 & 657,9 & 98,6 \\
\hline 2015 & 23015 & 92,7 & 562 & 116,1 & 580,7 & 88,3 \\
\hline
\end{tabular}

Źródło: opracowanie własne na podstawie Raportów o stanie rolnictwa ekologicznego w Polsce w latach 2004-2014 i materiałów z Ministerstwa Rolnictwa.

W ramach Unii Europejskiej tzw. reforma MacSharrey'go wprowadziła wsparcie finansowe rolnictwa ekologicznego, co wynikało z rozporządzenia Rady EWG 2978/92 o metodach gospodarowania przyjaznych środowisku naturalnemu i o rozwoju obszarów wiejskich. Wraz z tym

\footnotetext{
${ }^{1}$ Rozbieżność danych wynika $\mathrm{z}$ tego czy brano pod uwagę tylko gospodarstwa z certyfikatem, czy też wliczono w podane liczby powierzchnię gospodarstw w trakcie przestawiania się na produkcje ekologiczną.
} 
rozporządzeniem rolnictwo ekologiczne stało się integralnym elementem Wspólnej Polityki Rolnej. Od 1992 roku wsparcie rolnictwa ekologicznego było znaczącym czynnikiem stymulującym jego rozwój. Rozporządzenie Rady EWG 2078/92 zapoczątkowało również wprowadzenie programów rolnośrodowiskowych (green payments) stanowiąc zachętę finansową do podejmowania działalności ochronnej na rzecz rolnictwa i obszarów wiejskich (Golinowska, 2013, s. 50). Dzięki rozporządzeniom Rady EWG 2078/92 i Rady UE 1257/99 już w 2001 roku wsparcie rolnictwa ekologicznego w UE wynosiło 519385 tys. euro i zostało wypłacone 118656 beneficjentom użytkującym powierzchnię 2857135 ha (Łuczka-Bakuła, 2007).

Wstąpienie Polski do UE pozwoliło na większe wsparcie finansowe ekologicznych gospodarstw rolnych. Na początku środki napływały w ramach programów przedakcesyjnych, potem jako strumienie finansowe z Programu Rozwoju Obszarów Wiejskich (PROW) 2004-2006. Otrzymanie wsparcia na przedsięwzięcia rolno-środowiskowe i dotyczące poprawy dobrostanu zwierząt było uwarunkowane zobowiązaniem się beneficjenta płatności do realizacji tego programu w okresie 5 lat. Ostatnie płatności z funduszy PROW 2004-2006 były przyznane jeszcze polskim rolnikom w 2011 roku. Wsparcie rolnictwa ekologicznego ze środków PROW 20042006 realizowano w ramach Pakietu 2 - ,rolnictwo ekologiczne” w ramach Działania 4: „Wspieranie przedsięwzięć rolno-środowiskowych i poprawy dobrostanu zwierząt”. Realizacja pakietu polegała na podejmowaniu przez rolnika działań, mających przyczynić się do upowszechnienia systemów produkcji rolniczej, zgodnych z wymogami ochrony środowiska oraz ochrony zasobów genetycznych zwierząt gospodarskich. Pakiet „rolnictwo ekologiczne” (kod So2) zawierał osiem możliwych do realizacji wariantów (Raport o stanie..., 2007, s. 27).

Na realizację programu przewidziano 3592,4 mln euro środków publicznych (wkład wspólnotowy $2866 \mathrm{mln}$ euro, wkład polski $726 \mathrm{mln}$ euro). Część środków przeznaczono na uzupełnienie płatności bezpośrednich $(682,4 \mathrm{mln}$ euro) oraz na sfinansowanie działań Programu SAPARD, zatwierdzonych Rozporządzeniem Rady (WE) nr 1268/1999 (140,0 mln euro) (Bułakowska, Chmurzyńska, 2007, s. 9).

Kolejny program, w ramach którego przewidziano wsparcie rolnictwa ekologicznego w Polsce to PROW 2007-2013. Według założeń programu rolnicy ekologiczni uzyskiwali pomoc finansową realizując działania „Uczestnictwo rolników w systemie jakości żywności” lub „Działania informacyjne i promocyjne” z osi I „Poprawa konkurencyjności sektora rolnego i leśnego”. Jednocześnie wparcie finansowe można było uzyskać w ramach osi II „Poprawa środowiska naturalnego i obszarów wiejskich”, w działaniu 214 „Program rolno-środowiskowy (Płatności rolno-środowiskowe)” pakiet 2 - „rolnictwo ekologiczne”. Pakiet „,rolnictwo ekologiczne” obejmował już 12 możliwych do realizacji wariantów (Raport o stanie..., 2015, s. 25). W sumie w ramach PROW 2007-2013 do Polski trafiło w ramach II filara Wspólnej Polityki Rolnej ponad 17,4 mld euro. Tworzyły go unijne środki z Europejskiego Funduszu Rolnego na rzecz Rozwoju Obszarów Wiejskich (13,4 mld euro) i z budżetu krajowego (około 4 mld euro) ${ }^{2}$.

W tabeli 2 przedstawiono ile wniosków (tylko tych pozytywnie rozpatrzonych) złożyli rolnicy o wypłatę różnego rodzaju dofinansowania do działalności ekologicznej w wybranych latach. Przedstawiono również rozmiary obszaru rolnego objętego dotacjami i sumę dokonanych wypłat na rzecz polskich rolników gospodarujących metodami ekologicznymi.

\footnotetext{
${ }^{2}$ http://www.arimr.gov.pl/pomoc-unijna/prow-2007-2013-podstawowe-informacje.html.
} 
Tabela 2. Liczba wniosków, powierzchnia gospodarstw ekologicznych i kwoty wypłacone dla gospodarstw prowadzących produkcję metodami ekologicznymi w ramach PROW 2004-2006 i 2007-2013 w latach 2009-2014

\begin{tabular}{|c|c|c|c|c|c|c|}
\hline \multirow{2}{*}{ Rok } & \multicolumn{2}{|c|}{$\begin{array}{c}\text { Liczba pozytywnie } \\
\text { rozpatrzonych wniosków }\end{array}$} & \multicolumn{2}{c|}{$\begin{array}{c}\text { Powierzchnia } \\
\text { dofinansowania }\end{array}$} & \multicolumn{2}{c|}{$\begin{array}{c}\text { Wypłata } \\
\text { dofinansowania }\end{array}$} \\
\cline { 2 - 7 } & szt & dynamika (\%) & tys. ha & dynamika (\%) & zł & dynamika (\%) \\
\hline 2009 & 16642 & - & 380,7 & - & 257670994 & - \\
\hline 2010 & 20000 & 120,2 & 482,5 & 126,7 & 330836711 & 128,4 \\
\hline 2011 & 41588 & 207,9 & 539,9 & 111,9 & 341091447 & 103,1 \\
\hline 2012 & 55217 & 132,8 & 542,6 & 100,5 & 354794403 & 104,0 \\
\hline 2013 & 53527 & 96,9 & 589,9 & 108,7 & 407285458 & 114,8 \\
\hline 2014 & 47722 & 89,1 & 503,9 & 85,4 & 347501234 & 85,3 \\
\hline
\end{tabular}

Źródło: opracowano na podstawie: Raport o stanie... (2011, s. 42-52; 2013, s. 47-51; 2015, s. 41-44); materiały z FiBL i IFOAM.

Na podstawie danych zaprezentowanych w tabeli 2 policzono współczynniki korelacji liniowej Pearsona, które wykazały, że w latach 2009-2014 zachodzą bardzo silne, dodatnie zależności liniowe pomiędzy wysokością wypłaconego dofinansowania a liczbą ekologicznych gospodarstw rolnych $\left(\mathrm{r}_{\mathrm{xy}}=0,92\right)$ oraz powierzchnią ekologicznych użytków rolnych $\left(\mathrm{r}_{\mathrm{xy}}=0,89\right)$. Oznacza to, że im więcej środków jest wypłacanych na rzecz rolników prowadzących gospodarstwa ekologiczne, tym większe zainteresowanie powstawaniem nowych gospodarstw ekologicznych i przekazywaniem ziemi pod uprawy ekologiczne. Obecnie wsparcie rolnictwa ekologicznego w Polsce odbywa się na podstawie zapisów PROW na lata 2014-2020. Zgodnie z przepisami strumienie finansowe skierowane są na dwa poddziałania: Płatności w okresie konwersji na rolnictwo ekologiczne i Płatności w celu utrzymania rolnictwa ekologicznego. W ramach poddziałania (11.1) Płatności w okresie konwersji na rolnictwo ekologiczne, pomoc udzielana jest i będzie na następujące typy operacji (pakiety): Pakiet 1 . Uprawy rolnicze w okresie konwersji - 966 zł/ha; Pakiet 2. Uprawy warzywne w okresie konwersji - 1557 zł/ha; Pakiet 3. Uprawy zielarskie w okresie konwersji - $1325 \mathrm{zł}$ /ha; Pakiet 4. Uprawy sadownicze w okresie konwersji - 1882 zł/ha (podstawowe uprawy sadownicze) oraz 790 zł/ha (ekstensywne uprawy sadownicze); Pakiet 5. Uprawy paszowe na gruntach ornych w okresie konwersji - $787 \mathrm{zl} /$ ha oraz Pakiet 6. Trwałe użytki zielone w okresie konwersji - $428 \mathrm{zł} /$ ha. Z kolei w ramach poddziałania (11.2) Płatności w celu utrzymania rolnictwa ekologicznego pomoc udzielana będzie na następujące typy operacji (pakiety): Pakiet 7. Uprawy rolnicze po okresie konwersji - 792 zł/ha; Pakiet 8. Uprawy warzywne po okresie konwersji - 1310 zł/ha; Pakiet 9. Uprawy zielarskie po okresie konwersji - 1325 zł/ha; Pakiet 10. Uprawy sadownicze po okresie konwersji - 1501 zł/ha (podstawowe uprawy sadownicze) i $660 \mathrm{zt} /$ ha (ekstensywne uprawy sadownicze); Pakiet 11. Uprawy paszowe na gruntach ornych po okresie konwersji - 559 zł/ha; Pakiet 12 . Trwałe użytki zielone po okresie konwersji - 428 zł/ha. Stawki wypłacane w ramach PROW 2004-2006 i 2007-2013 zostały szczegółowo przedstawione w pracy J. Kondratowicz-Pozorskiej (2014, s. 110). Na lata 2014-2020 założono degresywność stawek, jak przy płatności rolno-środowiskowo-klimatycznej, tzn. płatność jest przyznawana do gruntów ornych w wysokości:

- 100\% stawki podstawowej - za powierzchnię od 0,10 ha do 50 ha,

- 75\% stawki podstawowej - za powierzchnię powyżej 50 ha do 100 ha, 
- $60 \%$ stawki podstawowej - za powierzchnię powyżej 100 ha.

Wsparcie udzielane w ramach Działania rolno-środowiskowo-klimatycznego nie może być udzielane na zobowiązania objęte działaniem Rolnictwo ekologiczne. W ramach jednego gospodarstwa mogą być realizowane zobowiązania zarówno w ramach Działania rolno-środowiskowo-klimatycznego, jak i działania Rolnictwo ekologiczne, pod warunkiem ich realizacji na innej powierzchni. Powyższe nie ma zastosowania w przypadku realizacji Pakietu 1. Rolnictwo zrównoważone oraz działania Rolnictwo ekologiczne, których nie można łączyć w gospodarstwie, gdyż w ramach Pakietu 1. Rolnictwo zrównoważone beneficjent realizuje zobowiązanie na obszarze całego gospodarstwa rolnego. W sumie na rolnictwo ekologiczne przeznaczono 445373661 euro ze środków unijnych, a razem z krajowymi - 699961515 euro³.

\section{Relacje pomiędzy wsparciem a rozwojem ekologicznych gospodarstw rolnych w Polsce}

Na podstawie danych zaprezentowanych w tabeli 1 i 2 można stwierdzić, że w latach 2009-2014 zanotowano, że:

1. Najmniejsze przyrosty (rok do roku poprzedniego) są charakterystyczne dla danych dotyczących poziomu dofinansowania rolnictwa ekologicznego ( 2010 r. to aż $+28,4 \%$ przyrostu finansowania, ale kolejne lata to już tylko wzrost o 3,14 i 4,02\%. Dopiero porównanie danych z roku 2013 daje pozytywny wynik dwucyfrowy w wysokości 14,8\%, jednak w następnym roku obserwuje się już ujemny przyrost $-15 \%$.

2. Najczęściej dwucyfrowe dodatnie przyrosty charakteryzują liczbę gospodarstw rolnych o charakterze ekologicznym. W 2009 roku dynamika wzrostu liczby omawianych gospodarstw była rzędu 14,7\%, potem kolejno 20,4; 13,9 i 10,6\%. Z kolei rok 2013 przynosi wzrost sięgający zaledwie $2,5 \%$, by w 2014 roku zmienić się w przyrost ujemny o wartości $6,7 \%$.

3. Stałą tendencję do obniżania wartości przyrostów mają dane dotyczące powierzchni ekologicznych gospodarstw rolnych objętych dopłatami z funduszy unijnych. Dynamika przyrostu powierzchni (rok do roku) w latach 2009-2014 to kolejno: 32,2; 24,7; 16,6; 9,3; $0,8 \mathrm{i}-1,8 \%$.

Można zatem stwierdzić, że dość dynamicznie rosnącej liczbie gospodarstw ekologicznych nie towarzyszy podobna dynamika wzrostu świadczeń finansowych. Ciekawy do dalszych szczegółowych badań jest malejący trend przyrostu powierzchni badanych podmiotów. Być może świadczy to o tym, że słabsze wyniki są świadectwem tego, iż na początku wielu producentów rolnych gospodarujących dotychczas konwencjonalnymi metodami zdecydowało ubiegać się o certyfikaty głównie z powodu wysokich dopłat do powierzchni upraw ekologicznych w czasie przestawienia. Z czasem okazało się jednak, że dopłaty nie są wystarczającym źródłem dochodu ani rekompensatą za ciężką i w większości pracochłonną pracę. Jak podaje Kowalska (2010) dotacje są tylko wyrazem docenienia starań prośrodowiskowych podejmowanych przez producentów rolnych i stanowią rekompensatę za spadki sprzedaży, a co za tym idzie - przychodów, zwłaszcza w okresie przejściowym. Obecnie rolnicy bardziej świadomie podejmują decyzję

\footnotetext{
${ }^{3}$ http://www.farmer.pl/finanse/dotacje-i-doplaty/rolnictwo-ekologiczne-w-prow-2014-2020,54837.html.
} 
o przestawieniu swoich gospodarstw, a jeżeli już to uczynią stawiają na ich rozwój (Kowalska, 2010, s. 52).

Przeliczając wysokość strumieni finansowych wypłacanych rolnikom w latach 2009-2014 w stosunku do liczby gospodarstw, które wówczas były zarejestrowane jako ekologiczne można stwierdzić, że przeciętne gospodarstwo dostawało jako rekompensatę za ekologiczne metody produkcji około 15 tys. zł w roku 2009, ponad 16 tys. - w 2010 roku i kolejno w następnych latach: około 14,5 tys., 13,3 tys., 15,3 i niecałe 14 tys. zł w 2014 roku. Można łatwo zauważyć, że wypłaty w roku 2010 były dla rolników najbardziej korzystne, ale kolejne lata nie dawały już optymistycznych perspektyw na przyszłość. Oczywiście w rzeczywistości wysokość wypłaty dla rolników była i jest uzależniona od powierzchni gospodarstwa i jego struktury. Przedstawione kwoty świadczą jednak o tym, że nie da się prowadzić gospodarstwa ekologicznego tylko dla pieniędzy uzyskanych ze środków unijnych, ale trzeba mieć do tego zamiłowanie.

Analizując wysokość strumieni finansowych wypłacanych rolnikom w latach 2009-2014 w stosunku do powierzchni gospodarstw, na które wówczas uzyskano dofinansowanie, można stwierdzić, że przeciętna wartość wypłacana rolnikowi do 1 ha powierzchni, na które złożyli wnioski statystycznie spada. Tendencję tę zaburzają jedynie nieznacznie notowania wartości z 2010 i 2013 roku. Ogólnie sytuacja przedstawia się następująco - wartość wsparcia finansowego na 1 ha gospodarstwa ekologicznego to przeciętnie 619 zł w 2009 roku, w kolejnym zaś roku - 637 zł. W latach 2011-2012 wysokości dopłat wynosiły odpowiednio 563 i 536 zł. Ponowny wzrost przeciętnej kwoty do poziomu 610,6 zł w 2013 roku (i tak niższej niż w latach 2009-2010) nie trwał jednak długo, bowiem rok później zaobserwowano ponowny spadek wartości kwoty dofinansowania 1 ha. Przeciętna wartość 528 zł z 2014 roku jest jednocześnie najniższą przeciętną kwotą jaka była w całym okresie objętym finansowaniem (2009-2014). Być może niewysokie stawki jakie przysługiwały rolnikom w przeliczeniu na 1 ha w 2011 i 2012 roku sprawiły, że ubyło ekologicznych gospodarstw rolnych i trend ten jest nadal aktualny również w 2015 roku.

\section{Podsumowanie}

Analiza danych dotyczących ekologicznych gospodarstw rolnych działających w Polsce w latach 2004-2015 przeprowadzona pod kątem czterech zmiennych, tj.:

- liczby gospodarstw ekologicznych,

- powierzchni omawianych podmiotów,

- liczby składanych wniosków o wsparcie finansowe w określonych wariantach działania,

- wysokości strumieni dofinansowania gospodarstw,

wskazuje, że w Polsce - podobnie jak w wielu krajach na zachodzie Europy - obserwuje się podobne zjawiska. Na początku obserwowano gwałtowny wzrost zainteresowania polskich rolników metodami ekologicznym. Apogeum tego zjawiska przypadło na lata 2005-2013. W tym samym czasie rolnikom wypłacano świadczenia w ramach PROW 2004-2006 i 2007-2014. Liczne i burzliwe debaty na temat jak i czy wspierać rolnictwo w Unii Europejskiej prowadzone przez polityków, ekspertów, dziennikarzy w związku ze zbliżającym się nowym okresem oddziaływania PROW sprawiły jednak, że rolnicy zrozumieli, iż nie wolno im zakładać w codziennej działalności, że dotacje zawsze będą ich wspierać. Być może ta niepewność jutra, jak i dołączenie do UE Chorwacji, która ma możliwości produkcji rolnej metodami ekologicznymi znacznie lepsze 
niż Polska, wpłynęło na spowolnienie tempa rozwoju ekologicznych gospodarstw rolnych. Praktycznie od roku 2010 tempo przyrostu nowych gospodarstw jest coraz niższe i proces ten trwał aż do 2013 roku. Po tym bowiem okresie notuje się już tempo przyrostu ujemne, tzn. podmiotów produkujących metodami ekologicznymi zaczyna ubywać.

Odpowiednio do opisanej powyżej sytuacji zachowuje się druga zmienna. Również tempo dodatnich przyrostów powierzchni gospodarstw ekologicznych w latach 2009-2013 systematycznie spadało, zaś po roku 2013 notowany jest już ujemny przyrost. Oznacza to, że nie tylko ubywa gospodarstw, ale również ubywa ziemi uprawianej w sposób ekologiczny. Nie zaskakuje więc analiza czwartej zmiennej, tj. danych dotyczących strumieni finansowych wspierających rolnictwo ekologiczne. Ich niewielkie przyrosty w granicach 3-4\% w latach 2011-2012 sprawiły, że w roku 2013 rolnicy musieli odpowiedzieć sobie na dwa trudne pytania: 1) czy na pewno wybrałem dobrą metodę gospodarowania i 2) jeżeli dofinansowanie rolnictwa ekologicznego w kolejnych latach będzie coraz niższe (lub go nie będzie), to czy gospodarstwo będzie przynosiło wystarczający dochód mojej rodzinie? Pozytywnych odpowiedzi na tak postawione pytania trudno udzielić, gdy przeanalizuje się przeciętną kwotę wsparcia w przeliczeniu na 1 gospodarstwo lub w przeliczeniu na 1 ha. W analizowanych latach 2009-2014 stwierdzono, że przeciętne kwoty dofinansowania są coraz niższe. Sytuację komplikuje dodatkowo fakt, że w tym czasie ceny na czynniki produkcji w rolnictwie są coraz wyższe, a ceny płodów coraz niższe. Ponadto ulepszono kontrolę gospodarstw ekologicznych i zwiększono kontrolę działań przy realizacji wniosków, na które rolnicy dostają dofinansowanie. Wszystko to sprawia, że ci gospodarze, którzy liczyli tylko na dotacje będą powoli odchodzić od rolnictwa ekologicznego. Trudno nazwać to zjawisko negatywnym, bowiem na rynku pozostaną ci, którym naprawdę zależy na produkcji i sprzedaży zdrowych, naturalnych produktów rolnych. Z całą pewnością można jednak zaryzykować stwierdzenie, że szczyt rozwoju ekologiczne gospodarstwa rolne w Polsce mają już za sobą.

\section{Literatura}

Bułakowska, M., Chmurzyńska, K. (2007). Wyniki realizacji PROW i SPO „Rolnictwo” w latach 2004-2006. Warszawa: IERiGŻ.

Golinowska, M. (2013). Rozwój rolnictwa ekologicznego. Wrocław: Wydawnictwo Uniwersytetu Przyrodniczego.

http://www.arimr.gov.pl/pomoc-unijna/prow-2007-2013-podstawowe-informacje.html.

http://www.farmer.pl/finanse/dotacje-i-doplaty/rolnictwo-ekologiczne-w-prow-2014-2020,54837.html.

Kondratowicz-Pozorska, J. (2013). Ekonomiczno-organizacyjne determinanty konkurencyjności ekologicznych gospodarstw rolnych $w$ Polsce. Szczecin: PTE o/Szczecin.

Kondratowicz-Pozorska, J. (2014). Wsparcie rolnictwa ekologicznego w Polsce w latach 2004-2013 i w perspektywie 2014-2020. Prace Naukowe Uniwersytetu Ekonomicznego we Wrocławiu, 361, 108-116.

Kowalska, A. (2010). Czynniki wpływające na rozwój rolnictwa ekologicznego w Polsce i innych krajach europejskich. Annales Universitatis Mariae Curie-Skłodowska, XLIV (H), 41-63.

Łuczka-Bakuła, W. (2007). Rynek żywności ekologicznej. Warszawa: PWE.

Raport o stanie rolnictwa ekologicznego w Polsce w latach 2004-2006 (2007). Warszawa.

Raport o stanie rolnictwa ekologicznego w Polsce w latach 2007-2008 (2009). Warszawa:. IJHARS.

Raport o stanie rolnictwa ekologicznego w Polsce w latach 2009-2010 (2011). Warszawa: IJHARS.

Raport o stanie rolnictwa ekologicznego w Polsce w latach 2011-2012 (2013). Warszawa: IJHARS. 
Raport o stanie rolnictwa ekologicznego w Polsce w latach 2013-2014 (2015). Warszawa.

Rolnictwo ekologiczne w Polsce w latach 1999-2000 (2001). Warszawa: Materiały Inspektoratu Skupu i Przetwórstwa Artykułów Rolnych.

Tyburski, J., Żakowska-Biemans, S. (2007). Wprowadzenie do rolnictwa ekologicznego. Warszawa: SGGW.

\section{Cytowanie}

Kondratowicz-Pozorska, J. (2016). Wpływ wsparcia z funduszy unijnych na rozwój rolnictwa ekologicznego w Polsce. Wspótczesne Finanse. Teoria i Praktyka, 1 (1), 15-23. DOI: 10.18276/wf.2016.1-02. 